\title{
Effect of Inoculation with Preactivated Lactobacillus Buchneri and Urea on Fermentative Profile, Aerobic Stability and Nutritive Value in Corn Silage
}

\author{
Ana Paula Maia dos Santos ${ }^{1}$, Edson Mauro Santos ${ }^{1}$, Gherman Garcia Leal de Araújo ${ }^{2}$, \\ Juliana Silva de Oliveira ${ }^{1}$, Anderson de Moura Zanine ${ }^{3}\left(\mathbb{D}\right.$, Ricardo Martins Araujo Pinho ${ }^{4} *$ (D), \\ Gabriel Ferreira de Lima Cruz ${ }^{1}$ (D), Daniele de Jesus Ferreira ${ }^{3}$, Alexandre Fernandes Perazzo ${ }^{3}$, \\ Danillo Marte Pereira ${ }^{1}$ and Francisco Naysson de Sousa Santos ${ }^{1}$ \\ 1 Department of Animal Science, Federal University of Paraíba, Rod Pb-079, Areia 58397-000, Brazil; \\ anapaula.zootecnia.al@gmail.com (A.P.M.d.S.); edsonzootecnista@yahoo.com.br (E.M.S.); \\ oliveirajs@yahoo.com.br (J.S.d.O.); g_ferreira_dm@hotmail.com (G.F.d.L.C.); \\ danillomarte.zootec@gmail.com (D.M.P.); nayssonzootecnista@gmail.com (F.N.d.S.S.) \\ 2 Brazilian Company of Agricultural Research, Rodovia BR-428, Km 152, S/N, Petrolina, \\ Pernambuco 56302-970, Brazil; gherman.araujo@embrapa.br \\ 3 Department of Animal Science, Federal University of Maranhão, Rodovia BR 222, km 4, s/n, Chapadinha, \\ Maranhão 65500-000, Brazil; anderson.zanine@ibest.com.br (A.d.M.Z.); \\ dany_dosanjos@yahoo.com.br (D.d.J.F.); alexandreperazzo@hotmail.com (A.F.P.) \\ 4 Department of Animal Science, Federal Institute of Education, Science and Technology of Ceara, CE-292, \\ S/N-Gisélia Pinheiro, Crato, Ceará 63155-500, Brazil \\ * Correspondence: ricardo-zootec@hotmail.com
}

Received: 26 June 2020; Accepted: 3 August 2020; Published: 6 August 2020

Abstract: The current study aimed to evaluate the application effects of the preactivated Lactobacillus buchneri and urea on the fermentative characteristics, chemical composition and aerobic stability in corn silages. The design was completely randomized, in a $6 \times 5$ factorial arrangement, with six types of additive and five opening times. The treatments consisted of corn silage; corn silage with freeze-dried inoculant; corn silage with freeze-dried inoculant $+1.0 \%$ urea; corn silage with activated inoculant; corn silage with activated inoculant $+1.0 \%$ urea, and corn silage with $1.0 \%$ urea. Populations of lactic acid bacteria stabilized at the 70th day, with average values of 8.91 and $9.15 \log \mathrm{cfu} / \mathrm{g}$ for corn silage with freeze-dried inoculant $+1.0 \%$ urea and corn silage with freeze-dried inoculant, respectively. In contrast, the silages without additives showed significantly lower values of $7.52 \log \mathrm{cfu} / \mathrm{g}$ forage at the 70th day. The silages with urea (isolated or associated with the inoculant) increased the total nitrogen content. The maximum temperature values were highest in the corn silages without additives, indicating that these silages were more prone to deterioration. The use of Lactobacillus buchneri activated proved to be more efficient in improving the fermentative profile of corn silages than the freeze-dried inoculant. The use of urea as an additive reduced the losses and improved the nutritional value and aerobic stability of corn silages. Additionally, the combination of Lactobacillus buchneri activated and urea may be used as a technique to improve the fermentative profile, chemical composition and aerobic stability of corn silages.

Keywords: acetic acid; aerobic deterioration; dry matter recovery; lactic acid bacteria; microbial inoculant; yeast 


\section{Introduction}

Silages that have desirable fermentation, with emphasis on lactic acid (LA) production, maintain their nutritional value with minimum losses, which promote a positive effect on animal production [1] and reduce environmental pollution [2].

Corn (Zea mays L.) is a species that stands out for silage production because of its high nutritional value, suitable dry matter (DM) content, high concentration of fermentable carbohydrates, low buffering capacity and high digestibility [3]. However, corn silages, due to the high concentrations of water-soluble carbohydrates (WSC), afford a high content of lactic acid that causes a sharp drop in pH below 3.8, which allows the yeast's development that deteriorates the silage in a short time with exposure to air [4], and because these microorganisms are facultative anaerobic leaven, the residual soluble sugars and also yeasts are able to assimilate lactate, starting aerobic deterioration [3,5-7]. According to [8], the corn plant may have 3 to $5 \log \mathrm{cfu} / \mathrm{g}$ epiphytic yeasts and the low concentration of fermentation products with antifungal capacity compromises the silage's aerobic stability $[9,10]$.

Thus, the inoculation of the forage during the ensiling process is a technique which reduces the growth of undesirable microorganisms and minimizes losses by secondary fermentations. Previous research indicated that inoculation during the forage's ensiling process is beneficial to the fermentation process of silages, [11-14] as well as for the aerobic stability.

Silage inoculates, when exposed to aerobic organisms, are effective in the control of fungi in a low $\mathrm{pH}$ medium, especially if the inoculation was performed with heterofermentative bacteria which use lactic acid and glucose as a substrate for acetic acid production.

Heterofermentative bacteria, such as Lactobacillus buchneri (LB), are able to synthesize significant amounts of acetic acid [11], whereas the lactic acid metabolism also produces 1,2-propanediol [15]. Furthermore, $L B$ produce ferulate-esterase, an enzyme that can weaken the plant cell wall to enzymatic hydrolysis, increasing the WSC availability to the silage fermentation process or use by rumen bacteria [16].

In addition, the inclusion of urea during the forage's ensiling process has been studied for also decreasing the losses from the silage fermentation process and to improve the aerobic stability mainly in corn silages such as inoculation with LAB during the ensilage process [16-19]. The urea fungistatic action promoted from the urea hydrolysis increases the concentration of ammonium, that is toxic to yeasts $[20,21]$. Ammonium prompts, to modify yeasts, nitrogen metabolism, since a nitrogen imbalance in the specific ratio of essential substrates to the yeast's growth results in slowing development $[20,21]$.

Urea still acts by interfering on the $\mathrm{pH}$ drop during the silage process, restricting the population growth of yeasts due to the buffering of the ensiled mass and raising the $\mathrm{pH}$ in a suitable range to the activity of lactic acid bacteria depending on the amount used $[19,22]$. The buffering of the ensiled mass can favor the growth of heterofermentative $\mathrm{LAB}$, due to the maintenance of the $\mathrm{pH}$ in an optimal range for the development of these microorganisms, which induce them to produce more acetic acid so that the $\mathrm{pH}$ is maintained in an optimal range in detriment of the lower production of lactic acid that could reduce the $\mathrm{pH}$, thus controlling the presence of yeasts in the ensiled mass, resulting in less alcoholic fermentation and increase in the silage's aerobic stability [22].

Therefore, we hypothesized that the use of previously activated LB with reconstituted skim milk (RSM) containing sucrose as an energy source, $24 \mathrm{~h}$ before ensiling, associated with urea can promote improvements in the fermentation profile, chemical composition and aerobic stability of the corn silage. Thus, the objective of this study was to evaluate the application effects of the preactivated Lactobacillus buchneri and urea on the fermentative characteristics, chemical composition and aerobic stability of corn silages. 


\section{Materials and Methods}

\subsection{Location and Climatic Conditions}

The experiment was conducted in the Forage Farming Sector of the Department of Animal Science of the Center of Agricultural Sciences, Federal University of Paraíba-UFPB, located in the mesoregion of Agreste and microregion of Brejo Paraibano, municipality of Areia, Brazil, at the coordinates of $06^{\circ} 57^{\prime} 46^{\prime \prime} \mathrm{S}$ and $35^{\circ} 41^{\prime} 31^{\prime \prime} \mathrm{W}, 623 \mathrm{~m}$ altitude.

According to data from the Meteorological Station of the Agricultural Sciences Center of the Federal University of Paraíba, the average annual rainfall in the municipality of Areia is $1400 \mathrm{~mm}$; the average annual temperature is $24.5^{\circ} \mathrm{C}$, and the average relative humidity is $80 \%$. The rainy four-month period occurs between April and July, with an average of $62 \%$ of the annual rainfall occurring during the four months.

\subsection{Experimental Design and Treatments}

The design was completely randomized, in a $6 \times 5$ factorial arrangement, with six different additives (corn silage (CS); corn silage with freeze-dried inoculant (CSFDI); corn silage with freeze-dried inoculant $+1.0 \%$ urea (CSFDIU); corn silage with activated inoculant (CSAI); corn silage with activated inoculant $+1.0 \%$ urea (CSAIU), and corn silage with $1.0 \%$ urea (CSU) and five opening periods $(1,3,7,14$ and 70 days post-ensiling), with five replications. The urea dose was determined based on the dry matter (DM) of the forage.

Corn hybrid (AG 1051; Agroceres, SP, Brazil) was seeded in May 2014 in a 0.5-ha area manually at an application rate of 50,000 seeds/ha (70-cm row spacing). At sowing, $250 \mathrm{~kg} / \mathrm{ha}$ of fertilizer, 8-28-16 (N-P-K), was applied, and a top-dressing of $250 \mathrm{~kg} / \mathrm{ha}$ of ammonium sulfate was applied 30 days later. Corn plants were harvested approximately 97 days after sowing, when kernels reached the milky/pasty stage at $262 \mathrm{~g} / \mathrm{kg}$ of DM. The plants were harvested $25 \mathrm{~cm}$ above the ground manually as whole plants, chopped in a stationary forage machine regulated to cut the forage into particles of approximately $2 \mathrm{~cm}$ in length and packed into quintuplicate polyvinyl chloride (PVC) experimental silos, with a volume of $5.3 \mathrm{dm}^{3}$ (length $300 \mathrm{~mm}$ and diameter $150 \mathrm{~mm}$ ), to achieve a final packing density of $600 \pm 20 \mathrm{~kg}$ of fresh matter $/ \mathrm{m}^{3}$. The PVC silos were equipped with a Bunsen's valve (which allowed gas to move out) and $1.0 \mathrm{~kg}$ of sand at the bottom (in order to drain the effluent) was used.

The inoculant used contained a strain of Lactobacillus buchneri (LB CNCM I-4323, Lallemand Animal Nutrition's). The freeze-dried inoculant was diluted in $100 \mathrm{~mL}$ distilled water and applied uniformly ( $2 \mathrm{~mL} / \mathrm{kg}$ forage) according to the manufacturer's recommendations for an application rate of $1 \times 10^{5} \mathrm{cfu} / \mathrm{g}$ fresh forage. The inoculant was preactivated at $10 \% \mathrm{RSM}$ for $24 \mathrm{~h}$ before ensiling [23]. For the blend, $10 \mathrm{~g}$ RSM was solubilized in $90 \mathrm{~mL}$ distilled water, adding $2 \mathrm{~g}$ sucrose as the energy source for microbial growth sterilized by autoclaving at $120^{\circ} \mathrm{C}$ for $15 \mathrm{~min}$. The inoculation was conducted according to manufacturer's specifications and then incubated in a biochemical oxygen demand (BOD) oven at $25^{\circ} \mathrm{C}$ for $24 \mathrm{~h}$.

After the microbial growth, the LAB were counted in the RSM after $24 \mathrm{~h}$, through MRS culture medium [24]. LAB populations of $2.1 \times 10^{8} \mathrm{cfu} / \mathrm{mL}$ were counted from the medium preactivated at $10 \%$ RSM and from the inoculant diluted in water were counted at $4.5 \times 10^{6} \mathrm{cfu} / \mathrm{mL}$.

A total of $2 \mathrm{~mL} / \mathrm{kg}$ forage of this mixture was applied with the sprayer aid.

The urea addition corresponded to $1.0 \%$ urea based on the DM of the material to be ensiled. The urea was diluted in $100 \mathrm{~mL}$ distilled water and applied homogeneously in the forage with the sprayer support.

All additives were mixed homogeneously prior to filling the experimental silos. Immediately, the compaction of the forage was carried out in the silos, aiming to reach a specific mass of $600 \mathrm{~kg} / \mathrm{m}^{3}$ of fresh matter. The silos were stored for $1,3,7,14$ and 70 days at the average temperature of $25^{\circ} \mathrm{C}$ before opening. 


\subsection{Evaluation of Fermentative Losses and Recovery of Dry Matter}

The silos were weighed at the packing day and after 70 days of the fermentation process to estimate the losses from the fermentation. In order to estimate the gases, effluent and recovery losses, the equations described by [25] were used.

Gas losses were calculated according to the equation: $\mathrm{GL}=(\mathrm{PCf}-\mathrm{PCa}) /(\mathrm{MFf} \times \mathrm{MSf}) \times 10,000$, in which: $\mathrm{GL}=$ gas losses $(\% \mathrm{DM}) ; \mathrm{PCf}=$ weight of full silo at sealing $(\mathrm{kg}) ; \mathrm{PCa}=$ weight of full bucket at opening $(\mathrm{kg}) ; \mathrm{MFf}=$ forage mass at sealing $(\mathrm{kg}) ; \mathrm{MSf}=$ forage dry matter concentration at closing $(\%)$.

Effluent losses were calculated by the equation: $\mathrm{EL}=[(\mathrm{PVf}-\mathrm{Tb})-(\mathrm{PVi}-\mathrm{Tb})] / \mathrm{MFi} \times 100$, in which: $\mathrm{EL}=$ effluent losses $(\mathrm{kg} / \mathrm{t} \mathrm{FM}) ; \mathrm{PVi}=$ weight empty bucket + sand weight at sealing $(\mathrm{kg}) ; \mathrm{PVf}=$ weight empty bucket + sand weight at opening $(\mathrm{kg}) ; \mathrm{Tb}=$ weight empty bucket $(\mathrm{kg}) ; \mathrm{MFi}=$ forage mass at sealing (kg).

Dry matter recovery was calculated according to the equation: $\mathrm{DMR}=(\mathrm{MFa} \times \mathrm{MSa}) /(\mathrm{MFf} \times \mathrm{MSf})$ $\times 100$, in which: DMR = dry matter recovery $(\%) ; \mathrm{MFf}=$ forage mass at sealing $(\mathrm{kg}) ; \mathrm{MSf}=$ forage dry matter concentration at sealing $(\%) ; \mathrm{MFa}=$ forage mass at opening $(\mathrm{kg}) ; \mathrm{MSa}=$ forage dry matter concentration at opening (\%).

\subsection{Fermentative Profile, Chemical Analysis and Aerobic Stability}

Before ensiling, a sample of the entire corn plant was collected to analyze the chemical composition and the counts of the corn plant microbial populations (Table 1).

Table 1. Chemical composition and microbial populations of the corn plant before ensiling.

\begin{tabular}{cc}
\hline Dry Matter $(\mathrm{g} / \mathbf{k g})$ & $\mathbf{2 6 2 . 5}$ \\
\hline Crude protein $(\mathrm{g} / \mathrm{kg} \mathrm{DM})$ & 62.10 \\
Ash $(\mathrm{g} / \mathrm{kg} \mathrm{DM})$ & 32.30 \\
NDFas $^{1}(\mathrm{~g} / \mathrm{kg} \mathrm{DM})$ & 548.3 \\
${ }^{1}$ Water-soluble carbohydrates $(\mathrm{g} / \mathrm{kg} \mathrm{DM})$ & 152.14 \\
Lactic acid bacteria $(\log \mathrm{cfu} / \mathrm{g})$ & 5.50 \\
Yeasts and molds $\left(\log { }^{2} \mathrm{cfu} / \mathrm{g}\right)$ & 4.30 \\
\cline { 2 - 2 }
\end{tabular}

Chemical composition analysis was performed at the Laboratory of Animal Nutrition and Food Evaluation of the UFPB. The samples were conditioned in paper bags, weighed and kept in an oven at $60^{\circ} \mathrm{C}$ for $48 \mathrm{~h}$, afterwards, they were milled in a Willey type mill with a $1 \mathrm{~mm}$ mesh sieve and subjected to analysis.

The chemical composition analysis of the dry matter (DM), ash and crude protein (CP) was conducted according to the methodologies described by [26]. The neutral detergent fiber (NDF) determination was performed in accordance with the described methodology by [27] with corrections to ashes and proteins.

The water extracts from the silage and fresh forage samples were prepared by homogenizing $25 \mathrm{~g}$ of sample in $225 \mathrm{~mL}$ of sterile Ringer's solution (Oxoid, Hampshire, UK) in an industrial blender for $1 \mathrm{~min}$, after this was divided into two portions.

One portion was subjected to serial dilutions ranging from 10-1 to 10-10 for microbial analysis. Pour plates were prepared with MRS (Difco, São Paulo, Brazil) agar for LAB, and Potato Dextrose Agar (PDA; Difco, Sao Paulo, Brazil) containing $1.5 \%$ of tartaric acid solution $(10 \% w / v)$ for yeasts and molds ( $\mathrm{Y}$ and $\mathrm{M}$ ). The MRS plates were incubated at $37^{\circ} \mathrm{C}$ for $48 \mathrm{~h}$ in BOD. The PDA plates were incubated aerobically at $25^{\circ} \mathrm{C}$ for 5 days. All colonies were counted on plates with 30 to 300 colony-forming units (CFU).

In another water extract portion, the $\mathrm{pH}$ was measured using a potentiometer. After this, the water extracts were also assessed for organic acids (lactic acid, acetic acid, propionic acid and butyric acid) and ethanol [28], ammonia-nitrogen $\left(\mathrm{NH}_{3}-\mathrm{N}\right), \mathrm{pH}$ [29] and WSC [30]. 
The corn silages' aerobic stability was determined from samples of approximately $2 \pm 0.3 \mathrm{~kg}$ of silage taken from each silo. The samples were relocated in silos cleaned without compaction and exposed to air at $22^{\circ} \mathrm{C}$. T, the internal temperature, was measured every $1 \mathrm{~h}$ using a digital immersion thermometer inserted into the silage mass at the geometric center. Each silo was covered with a double layer of sterile cheesecloth to avoid contamination and drying of the silage but allowing air to infiltrate the silage mass. The ambient temperature was recorded through a thermometer suspended in the air. The aerobic stability was calculated as the number of hours before the silage mass temperature reached $2{ }^{\circ} \mathrm{C}$ above room temperature [31].

\subsection{Statistical Analyses}

The results obtained were subjected to analysis of variance, using PROC GLM of the software SAS 9.3 (SAS Institute Inc, Cary, NC, USA), verifying the normality of residues and homogeneity of variances using PROC UNIVARIATE. When the F value was significant $(p<0.05)$, the averages were compared by LSMEANS using the Tukey's test at a $5 \%$ significance level $(p<0.05)$.

\section{Results and Discussion}

\subsection{Fermentation Losses and Dry Matter Recovery of Silages}

As can be observed in Table 2, all silages showed low percentages of fermentation losses, thus indicating a good fermentation of the silages. Losses during the fermentation process of the silages can be quantified through the disappearance of the dry matter or energy. The main cause of losses from the biochemical and microbiological processes in the ensiled mass include the residual respiration, type of fermentation inside the silo, production of effluents and gases and activity of undesirable microorganisms [23,32].

Table 2. Values of fermentative losses and recovery of dry matter in corn silage.

\begin{tabular}{ccccc}
\hline \multirow{2}{*}{ Treatments $^{+}$} & \multicolumn{4}{c}{ Fermentative Losses } \\
\cline { 2 - 5 } & DML (\% DM) & GL (\%DM) & EL (kg/ton FM) & DMR (\% DM) \\
\hline CS & $5.38^{\mathrm{a}}$ & $2.67^{\mathrm{b}}$ & $16.00^{\mathrm{a}}$ & $94.61^{\mathrm{c}}$ \\
CSFDI & $5.07^{\mathrm{a}}$ & $3.17^{\mathrm{b}}$ & $16.00^{\mathrm{a}}$ & $94.92^{\mathrm{c}}$ \\
CSFDIU & $5.17^{\mathrm{a}}$ & $3.28^{\mathrm{b}}$ & $15.90^{\mathrm{a}}$ & $94.82^{\mathrm{c}}$ \\
CSAI & $4.32^{\mathrm{bc}}$ & $5.55^{\mathrm{a}}$ & $15.55^{\mathrm{bc}}$ & $95.67^{\mathrm{ab}}$ \\
CSAIU & $4.84^{\mathrm{ab}}$ & $3.91^{\mathrm{b}}$ & $15.60^{\mathrm{b}}$ & $95.15^{\mathrm{bc}}$ \\
CSU & $3.85^{\mathrm{c}}$ & $2.92^{\mathrm{b}}$ & $15.40^{\mathrm{c}}$ & $96.14^{\mathrm{a}}$ \\
SEM & 0.1950 & 1.9906 & 0.0065 & 0.1951 \\
$p$ value & $<0.001$ & $<0.001$ & $<0.001$ & $<0.001$ \\
\hline
\end{tabular}

+ Treatments: DML, dry matter losses; DM, dry matter; GL, gas losses; EL, effluent losses; FM, fresh matter; DMR, dry matter recovery; CS, corn silage; CSFDI, corn silage with freeze-dried inoculant; CSFDIU, corn silage with freeze-dried inoculant $+1.0 \%$ urea; CSAI, corn silage with activated inoculant; CSAIU, corn silage with activated inoculant $+1.0 \%$ urea; CSU, corn silage with $1.0 \%$ urea; means with different superscript letters in the columns are differed $(p<0.05)$.

Corn silages without additives and inoculated with microorganisms had similar DM loss values. The silages with urea, however, resulted in DM losses significantly lower than the other silages $(p<0.05)$ (Table 2). This can be explained because urea is a chemical additive capable of improving the fermentation process of silages. Consequently, it reduces nutrient losses by decreasing the yeast activity; it also minimizes alcoholic fermentation by making the silage $\mathrm{pH}$ drop slowly since $\mathrm{Y}$ and $\mathrm{M}$ have the most intense activity in more acidic silages [19]. The same authors observed the efficiency of urea in reducing dry matter losses (DML), where the level of $1.0 \%$ in the fresh matter (FM) presented the lower DML (5.31\%) compared to the control silage (8.59\%) at a DM content of $211.8 \mathrm{~g} / \mathrm{kg}$.

The gas losses were highest $(p<0.05)$ in silages with activated inoculant $(5.55 \%)$ (Table 2$)$. The heterofermentative bacteria are capable of producing LA and a considerable amount of AA, 
including ethanol, $\mathrm{CO}_{2}$ and other metabolites [33]. Thus, the highest values of gas production in the silages inoculated with previously activated bacteria can be explained by the heterofermentative metabolism of these microorganisms.

The silages with urea added had lower effluent production $(p<0.05)$, followed by silages with microbial inoculants activated alone or in combination with urea (Table 2). The values observed were lower than those described by [19] in corn silages with 1.0 and $2.0 \%$ urea, with values of 70.74 and $77.73 \mathrm{~kg} /$ ton in the fresh matter (FM), respectively. This result may be explained possibly due to the lower dry DM contents as a function of the corn harvest period of the present study.

There was a significant difference between the dry matter recovery (DMR) of the silages $(p<0.05)$, especially the silage ensiled with urea and the silage with activated inoculant, which had the highest percentage values (Table 2). This is possibly justified by the anti-microbial action of urea, which reduces the yeast development in the ensiled forage, and also the greater number of LAB present in the activated inoculant. The DMR values observed in the present study were similar to those recorded by [13] of $96.74 \%$ in corn silages inoculated with LB $(344.1 \mathrm{~g} / \mathrm{kg}$ DM), and lower than those verified by [12], who observed the recovery of $99 \%$ of dry matter in corn silages inoculated with LB $(331.0 \mathrm{~g} / \mathrm{kg} \mathrm{DM})$.

\subsection{Silage Fermentation Profile}

The fermentation profile of the silages varied significantly among the different silos' opening periods $(p<0.05)$ (Table 3$)$. The LA values in the silages differed significantly between treatments at all opening periods (Table 3 ). After $24 \mathrm{~h}$ of fermentation (day 1 ), the silages inoculated with activated $L B$ had the highest LA concentration $(p<0.05)$. The higher LA production rate was predicted in this case because the active LAB had a greater number with inoculation in the ensiled mass. The silages treated with freeze-dried inoculant had lower levels of LA $(p<0.05)$ (Table 3$)$.

The LA concentration in the silages without additives had a peak on the 14th day of fermentation. However, the highest values on that day occurred in the corn silage with freeze-dried inoculant $+1.0 \%$ urea (CSFDIU) and corn silage with activated inoculant $+1.0 \%$ urea (CSAIU), respectively (Table 3 ). The production of organic acids in the ensiled corn silage reflects the fermentative quality within the silo and the degree of activity of the microorganism's presence. Lactic acid is the main organic acid involved in the acidification of silages.

The silages added with urea had the highest LA concentration at 7 and 70 days of ensiling (Table 3 ). The hydrolysis of urea occurs in the first hours of the fermentation process, raising the corn silage $\mathrm{pH}$ and resistance to fast and intense acidification. Probably, the LAB development was favored due to the persistence of the higher $\mathrm{pH}$ and optimal $\mathrm{pH}$ of the silages.

At 70 days of fermentation, the silages without inoculants and the silages ensiled with activated inoculant isolated and associated with urea had significantly higher concentrations of acetic acid (AA) $(p<0.05)$, with values of 28.50, 29.67 and $28.92 \mathrm{~g} / \mathrm{kg} \mathrm{DM}$, respectively (Table 3$)$. The values were higher than those observed by [13] in silages inoculated with LB. AA is a substance with antimycotic properties and has been considered an important organic acid, involved in raising the silages' aerobic stability. Due to the slow growth of LB in the silo, its effectiveness in convert lactic to acetic acid normally needs at least 45 to 60 days [5].

In the phase of opening and supplying a silage, by exposing the ensiled forage to oxygen, the lactate assimilation by the $\mathrm{Y}$ and $\mathrm{M}$ begins the deterioration process, when lactic acid and residual carbohydrates are metabolized, producing carbon dioxide and water [34]. Thus, the silage $\mathrm{pH}$ increases, influencing other aerobic microorganisms' development and spoiling the silage [8,19]. The higher concentration of AA in silages may reduce these opportunistic aerobic microorganisms, preserving the ensiled mass and increasing the resistance to aerobic deterioration. The silages inoculated with freeze-dried inoculant associated with urea presented lower acetic acid values $(p<0.05)$ in all opening periods (Table 3), as well as the silages treated with freeze-dried inoculant on the 14th day of fermentation. The fermentation process of silages without additives resulted in higher values of 
propionic acid (PA) in the silages $(0.66 \mathrm{~g} / \mathrm{kg} \mathrm{DM})$. The treatment of silages with urea reduced the production of PA in the silages.

Table 3. Mean values of organic acids and ethanol concentrations in corn silages.

\begin{tabular}{|c|c|c|c|c|c|}
\hline \multirow{2}{*}{ Items $^{+}$} & \multicolumn{5}{|c|}{ Fermentation Periods (Days) } \\
\hline & 1 & 3 & 7 & 14 & 70 \\
\hline \multicolumn{6}{|c|}{ Lactic Acid (g/kg DM) } \\
\hline CS & $43.24^{d}$ & $49.51 \mathrm{bc}$ & $46.02^{c}$ & $57.66^{\mathrm{b}}$ & $46.61^{\mathrm{ab}}$ \\
\hline CSFDI & $50.46^{\mathrm{bc}}$ & $51.15^{\mathrm{abc}}$ & $45.01^{\mathrm{c}}$ & $49.65^{c}$ & $34.14^{\mathrm{d}}$ \\
\hline CSFDIU & $45.76^{\mathrm{c}}$ & $47.52^{c}$ & $47.99 \mathrm{abc}$ & $68.01^{\mathrm{a}}$ & $42.39^{\mathrm{bc}}$ \\
\hline CSAI & $57.38^{\mathrm{a}}$ & $56.01^{\mathrm{a}}$ & $51.60^{\mathrm{ab}}$ & $49.76^{c}$ & $38.56^{\mathrm{cd}}$ \\
\hline CSAIU & $47.29 \mathrm{~b}$ cd & $54.97^{\mathrm{a}}$ & $46.75^{b c}$ & $71.15^{\mathrm{a}}$ & $46.11^{\mathrm{ab}}$ \\
\hline CSU & $51.31^{\mathrm{b}}$ & $52.75^{\mathrm{ab}}$ & $52.32^{\mathrm{a}}$ & $53.21^{b c}$ & $47.55^{\mathrm{a}}$ \\
\hline$p$ value & $<0.001$ & $<0.001$ & $<0.001$ & $<0.001$ & $<0.001$ \\
\hline \multicolumn{6}{|c|}{ Acetic Acid (g/kg DM) } \\
\hline CS & $25.18^{\mathrm{b}}$ & $30.49^{\mathrm{a}}$ & $23.90^{\mathrm{a}}$ & $22.97^{\mathrm{d}}$ & $28.50^{\mathrm{a}}$ \\
\hline CSFDI & $28.34^{\mathrm{a}}$ & $22.65^{\mathrm{b}}$ & $21.22^{b}$ & $18.38^{\mathrm{e}}$ & $21.89^{b}$ \\
\hline CSFDIU & $16.26^{c}$ & $21.18^{b}$ & $21.02 \mathrm{bc}$ & $19.19^{\mathrm{e}}$ & $15.16^{\mathrm{c}}$ \\
\hline CSAI & $26.12^{b}$ & $28.95^{a}$ & $18.90^{\mathrm{c}}$ & $25.41^{\mathrm{c}}$ & $29.67^{\mathrm{a}}$ \\
\hline CSAIU & $25.77^{\mathrm{b}}$ & $17.80^{\mathrm{c}}$ & $20.83^{b c}$ & $32.62^{a}$ & $28.92^{\mathrm{a}}$ \\
\hline $\mathrm{CSU}$ & $25.85^{\mathrm{b}}$ & $29.84^{\text {a }}$ & $20.03 \mathrm{bc}$ & $28.52^{b}$ & $21.38^{b}$ \\
\hline$p$ value & $<0.001$ & $<0.001$ & $<0.001$ & $<0.001$ & $<0.001$ \\
\hline \multicolumn{6}{|c|}{ Propionic Acid (g/kg DM) } \\
\hline CS & $0.45^{\mathrm{c}}$ & $0.51^{\mathrm{b}}$ & $0.45^{b}$ & $0.47^{b}$ & $0.66^{\mathrm{a}}$ \\
\hline CSFDI & $1.01^{\mathrm{a}}$ & $0.73^{a b}$ & $0.77^{\mathrm{a}}$ & $0.82^{a}$ & $0.46^{a b}$ \\
\hline CSFDIU & $0.66^{\mathrm{bc}}$ & $0.56^{\mathrm{b}}$ & $0.46^{\mathrm{b}}$ & $0.51^{b}$ & $0.40^{\mathrm{b}}$ \\
\hline CSAI & $0.91^{\mathrm{a}}$ & $0.89^{a}$ & $0.50^{b}$ & $0.45^{b}$ & $0.38^{\mathrm{b}}$ \\
\hline CSAIU & $0.80^{\mathrm{ab}}$ & $0.53^{b}$ & $0.48^{b}$ & $0.46^{b}$ & $0.49^{a b}$ \\
\hline $\mathrm{CSU}$ & $0.51^{\mathrm{c}}$ & $0.54^{b}$ & $0.44^{\mathrm{b}}$ & $0.47^{b}$ & $0.41^{\mathrm{b}}$ \\
\hline$p$ value & $<0001$ & $<0001$ & 0.0015 & 0.0001 & 0.0026 \\
\hline \multicolumn{6}{|c|}{ Butyric Acid (g/kg DM) } \\
\hline CS & $0.35^{\mathrm{b}}$ & $0.39^{\mathrm{c}}$ & $0.34^{\mathrm{c}}$ & $0.41^{\mathrm{a}}$ & $0.39^{\mathrm{a}}$ \\
\hline CSFDI & $0.48^{\mathrm{a}}$ & $0.39^{\mathrm{c}}$ & $0.49^{\mathrm{a}}$ & $0.46^{\mathrm{a}}$ & $0.38^{\mathrm{ab}}$ \\
\hline CSFDIU & $0.45^{\mathrm{ab}}$ & $0.40^{\mathrm{c}}$ & $0.42^{b}$ & $0.27^{b}$ & $0.27^{c}$ \\
\hline CSAI & $0.38^{b}$ & $0.47^{\mathrm{b}}$ & $0.46^{\mathrm{ab}}$ & $0.41^{\mathrm{a}}$ & $0.33^{b}$ \\
\hline CSAIU & $0.44^{\mathrm{a}}$ & $0.53^{\mathrm{ab}}$ & $0.48^{\mathrm{a}}$ & $0.43^{a}$ & $0.40^{\mathrm{a}}$ \\
\hline CSU & $0.49^{\mathrm{a}}$ & $0.47^{\mathrm{b}}$ & $0.48^{\mathrm{a}}$ & $0.43^{\mathrm{a}}$ & $0.38^{a b}$ \\
\hline$p$ value & $<0.001$ & $<0.001$ & $<0.001$ & $<0.001$ & $<0.001$ \\
\hline \multicolumn{6}{|c|}{ Ethanol (g/kg DM) } \\
\hline CS & $48.47^{\mathrm{a}}$ & $30.20^{\mathrm{a}}$ & $22.68^{b}$ & $24.77^{a}$ & $32.63^{a}$ \\
\hline CSFDI & $41.77^{\mathrm{b}}$ & $7.45^{c}$ & $13.69^{c}$ & $15.06^{\mathrm{d}}$ & $26.80^{b}$ \\
\hline CSFDIU & $25.84^{\mathrm{e}}$ & $7.27^{c}$ & $25.72^{\mathrm{a}}$ & $15.64^{\mathrm{d}}$ & $20.66^{c}$ \\
\hline CSAI & $34.19^{c}$ & $25.83^{b}$ & $9.46^{\mathrm{d}}$ & $17.23^{\mathrm{cd}}$ & $21.72^{c}$ \\
\hline CSAIU & $35.80^{\mathrm{c}}$ & $9.62^{c}$ & $9.48^{\mathrm{d}}$ & $20.19^{b}$ & $29.31^{b}$ \\
\hline CSU & $31.04^{\mathrm{d}}$ & $9.53^{c}$ & $12.94^{\mathrm{c}}$ & $19.90^{b c}$ & $21.95^{c}$ \\
\hline$p$ value & $<0.001$ & $<0.001$ & $<0.001$ & $<0.001$ & $<0.001$ \\
\hline
\end{tabular}

${ }^{\dagger}$ Items: CS, corn silage; CSFDI, corn silage with freeze-dried inoculant; CSFDIU, corn silage with freeze-dried inoculant $+1.0 \%$ urea; CSAI, corn silage with activated inoculant; CSAIU, corn silage with activated inoculant $+1.0 \%$ urea; CSU, corn silage with $1.0 \%$ urea; means with different superscript letters in the columns are differed $(p<0.05)$.

Silages with freeze-dried inoculant associated with urea resulted in lower values of butyric acid (BA, $0.27 \mathrm{~g} / \mathrm{kg}$ DM). Higher values were observed in silages without additives $(0.39 \mathrm{~g} / \mathrm{kg} \mathrm{DM})$ and in silages treated with activated inoculant associated with urea $(0.40 \mathrm{~g} / \mathrm{kg} \mathrm{DM})$ at 70 days (Table 3). Despite the lower values observed in the silages with freeze-dried inoculant associated with urea, the silages generally showed much lower quantities than that recommended for a good-quality silage. Similarly, [35] reported that the presence of BA in ratios equal to or greater than $0.1 \%$ is indicative of undesirable fermentation during silage, which may decrease the quality of the final product. The low 
butyric acid values observed in the present study may be related to low $\mathrm{pH}$ values in the silages (Table 4) and low gas losses (Table 2), especially in silages with freeze-dried inoculant associated with urea, which resulted in lower values of butyric acid.

Table 4. Mean values of $\mathrm{pH}$, ammonia nitrogen, water-soluble carbohydrates and lactic acid bacteria (LAB) and yeasts and molds ( $\mathrm{Y}$ and $\mathrm{M})$ populations in corn silages.

\begin{tabular}{|c|c|c|c|c|c|}
\hline \multirow{2}{*}{ Items $^{+}$} & \multicolumn{5}{|c|}{ Fermentation Periods (Days) } \\
\hline & 1 & 3 & 7 & 14 & 70 \\
\hline \multicolumn{6}{|c|}{$\mathrm{pH}$} \\
\hline CS & $3.52^{b}$ & $3.52^{d}$ & $3.63^{b c}$ & $3.43^{\mathrm{d}}$ & $3.52^{d}$ \\
\hline CSFDI & $3.56^{b}$ & $3.81^{\mathrm{c}}$ & $3.68^{a b c}$ & $3.61 \mathrm{bc}$ & $3.72 b c$ \\
\hline CSFDIU & $3.76^{\mathrm{a}}$ & $3.96^{\mathrm{ab}}$ & $3.84^{\mathrm{a}}$ & $3.72^{a b}$ & $3.88^{b}$ \\
\hline CSAI & $3.51^{b}$ & $3.65^{\mathrm{cd}}$ & $3.61^{c}$ & $3.46^{\mathrm{cd}}$ & $3.66^{\mathrm{cd}}$ \\
\hline CSAIU & $3.81^{\mathrm{a}}$ & $3.96^{\mathrm{ab}}$ & $3.80^{a b}$ & $3.81^{\mathrm{a}}$ & $3.81^{b c}$ \\
\hline CSU & $3.83^{a}$ & $3.98^{\mathrm{a}}$ & $3.78 \mathrm{abc}$ & $3.68^{a b}$ & $4.09^{\mathrm{a}}$ \\
\hline$p$ value & $<0.001$ & $<0.001$ & $<0.001$ & $<0.001$ & $<0.001$ \\
\hline \multicolumn{6}{|c|}{ Ammonia Nitrogen $\left(\mathrm{NH}_{3} / \mathrm{TN}\right)$} \\
\hline CS & $0.05^{c}$ & $0.12^{b}$ & $0.34^{c}$ & $0.62 b c$ & $0.55^{c}$ \\
\hline CSFDI & $0.13^{b c}$ & $0.20^{b}$ & $0.51^{\mathrm{c}}$ & $0.71^{\mathrm{b}}$ & $0.49^{c}$ \\
\hline CSFDIU & $1.14^{\mathrm{a}}$ & $0.99^{a}$ & $1.87^{\mathrm{a}}$ & $1.46^{\mathrm{a}}$ & $1.44^{b}$ \\
\hline CSAI & $0.58^{b}$ & $0.14^{b}$ & $0.36^{c}$ & $0.33^{c}$ & $0.57^{c}$ \\
\hline CSAIU & $1.07^{\mathrm{a}}$ & $1.17^{\mathrm{a}}$ & $1.08^{b}$ & $1.40^{\mathrm{a}}$ & $1.73^{\mathrm{a}}$ \\
\hline CSU & $1.20^{\mathrm{a}}$ & $1.25^{\mathrm{a}}$ & $1.15^{\mathrm{b}}$ & $1.55^{\mathrm{a}}$ & $1.55^{\mathrm{ab}}$ \\
\hline$p$ value & $<0.001$ & $<0.001$ & $<0.001$ & $<0.001$ & $<0.001$ \\
\hline \multicolumn{6}{|c|}{ Water-Soluble Carbohydrates (g/kg DM) } \\
\hline CS & $110.45^{\mathrm{a}}$ & $61.93^{\mathrm{b}}$ & $58.84^{\mathrm{b}}$ & $68.20^{\mathrm{b}}$ & $67.09^{b}$ \\
\hline CSFDI & $100.66^{\mathrm{ab}}$ & $55.87^{\mathrm{b}}$ & $63.86^{\mathrm{ab}}$ & $79.16^{\mathrm{b}}$ & $89.68^{a}$ \\
\hline CSFDIU & $110.82^{\mathrm{a}}$ & $72.85^{\mathrm{ab}}$ & $80.96^{\mathrm{a}}$ & $78.29^{b}$ & $86.32^{\mathrm{a}}$ \\
\hline CSAI & $98.18^{a b}$ & $96.23^{a}$ & $84.23^{\mathrm{a}}$ & $75.34^{\mathrm{b}}$ & $86.25^{\mathrm{a}}$ \\
\hline CSAIU & $81.63^{b}$ & $60.35^{b}$ & $71.61^{\mathrm{a}}$ & $90.88^{a}$ & $84.19^{\mathrm{a}}$ \\
\hline CSU & $90.82^{\mathrm{ab}}$ & $63.86^{\mathrm{b}}$ & $68.54^{\mathrm{a}}$ & $86.15^{\mathrm{a}}$ & $87.19^{\mathrm{a}}$ \\
\hline$p$ value & 0.0140 & 0.0004 & $<0.001$ & 0.0084 & 0.0165 \\
\hline \multicolumn{6}{|c|}{ LAB (log cfu/g Forage) } \\
\hline CS & $8.43^{c}$ & $8.62^{c}$ & $8.70^{\mathrm{d}}$ & $7.95^{c}$ & $7.52^{b}$ \\
\hline CSFDI & $8.64^{c}$ & $8.60^{c}$ & $9.51^{\mathrm{c}}$ & $8.29^{b}$ & $9.15^{\mathrm{a}}$ \\
\hline CSFDIU & $9.20^{b}$ & $9.69^{b}$ & $8.77^{\mathrm{d}}$ & $8.13 \mathrm{bc}$ & $8.91^{\mathrm{a}}$ \\
\hline CSAI & $11.00^{\mathrm{a}}$ & $10.90^{\mathrm{a}}$ & $11.60^{\mathrm{a}}$ & $8.82^{\mathrm{a}}$ & $8.94^{\mathrm{a}}$ \\
\hline CSAIU & $8.44^{c}$ & $8.47^{c}$ & $10.48^{\mathrm{b}}$ & $7.97^{b c}$ & $8.95^{a}$ \\
\hline CSU & $8.39^{c}$ & $8.36^{\mathrm{c}}$ & $8.66^{\mathrm{d}}$ & $7.90^{\mathrm{c}}$ & $9.01^{\mathrm{a}}$ \\
\hline$p$ value & $<0.001$ & $<0.001$ & $<0.001$ & $<0.001$ & $<0.001$ \\
\hline \multicolumn{6}{|c|}{$\mathrm{Y}$ and $\mathrm{M}(\log \mathrm{cfu} / \mathrm{g}$ Forage $)$} \\
\hline CS & $5.51^{\mathrm{a}}$ & $5.27^{\mathrm{a}}$ & 5.41 & 5.65 & $4.86^{b}$ \\
\hline CSFDI & $5.33^{\mathrm{a}}$ & $5.27^{\mathrm{a}}$ & 5.54 & 5.96 & $4.65^{b}$ \\
\hline CSFDIU & $5.37^{\mathrm{a}}$ & $5.43^{\mathrm{a}}$ & 5.76 & 5.99 & $4.65^{b}$ \\
\hline CSAI & $5.16^{\mathrm{a}}$ & $5.47^{\mathrm{a}}$ & 5.24 & 5.57 & $5.17^{\mathrm{a}}$ \\
\hline CSAIU & $3.28^{b}$ & $5.04^{\mathrm{ab}}$ & 5.72 & 5.61 & $4.70^{\mathrm{b}}$ \\
\hline CSU & $3.12^{b}$ & $4.85^{\mathrm{b}}$ & 5.49 & 5.79 & $3.95^{c}$ \\
\hline$p$ value & $<0.001$ & $<0.001$ & $<0.001$ & $<0.001$ & $<0.001$ \\
\hline
\end{tabular}

+ Items: CS, corn silage; CSFDI, corn silage with freeze-dried inoculant; CSFDIU, corn silage with freeze-dried inoculant $+1.0 \%$ urea; CSAI, corn silage with activated inoculant; CSAIU, corn silage with activated inoculant $+1.0 \%$ urea; CSU, corn silage with $1.0 \%$ urea; means with different superscript letters in the columns are differed $(p<0.05)$.

The ethanol contents in corn silages without additives were high in all fermentation periods, especially on days 1 and 70, with values of 48.47 and $32.63 \mathrm{~g} / \mathrm{kg} \mathrm{DM}$, respectively. Lower values were observed at 70 days in silages with urea, silages with freeze-dried inoculant associated with urea 
and silages with an activated inoculant, with contents of 21.95, 20.66 and $21.72 \mathrm{~g} / \mathrm{kg} \mathrm{DM}$, respectively (Table 3).

The activity of $\mathrm{Y}$ and $\mathrm{M}$ in the ensiled mass is primarily reflected by the ethanol content in the silages, although heterofermentative LAB is capable of producing ethanol and other types of metabolites [15]. The $\mathrm{pH}$ values of silages with urea were significantly higher $(p<0.05)$ than those observed in corn silages without additives and the inoculated ones (Table 4). The addition of urea to the ensiled mass resulted in $\mathrm{pH}$ values and an LA concentration suitable for silage due to the buffering capacity of ammonia, avoiding a drastic reduction in $\mathrm{pH}$, corroborating the hypothesis of buffering acting as a controller of the yeast activity in the silo. The mean $\mathrm{pH}$ values observed in the silages inoculated with freeze-dried inoculant are similar to those verified by [12], who recorded values of $\mathrm{pH}$ of 3.65 in corn silages inoculated with LB strains.

The $\mathrm{pH}$ values in corn silages without additives and silages inoculated with pre-activated microorganisms were significantly lower than the other silages $(p<0.05)$ (Table 4$)$.

Silages inoculated with LB may show higher contents of $\mathrm{NH}_{3}-\mathrm{N}$ when compared to non-inoculated silages. In the present study, the highest $\mathrm{NH}_{3}-\mathrm{N}$ concentration resulted from the inoculation associated with the $\mathrm{pH}$ increase in silages inoculated with LB (Table 4).

High concentrations of $\mathrm{NH}_{3}-\mathrm{N}$ can indicate increased homolactic fermentation in silages [12], which tends to be predominant in silage. According to [35,36], the number of LAB required for a marked $\mathrm{pH}$ reduction in the ensiled mass is about $8.0 \mathrm{log} \mathrm{cfu} / \mathrm{g}$ forage, being that the number of LAB observed in the silages with isolated urea and inoculant and/or associated was superior to those described by these authors in the present study and what that means. For the concentration of total WSC, there was a significant difference $(p<0.05)$ among treatments in all opening periods (Table 4 ). In the first $24 \mathrm{~h}$ of fermentation, silages inoculated with preactivated bacteria associated with urea showed significantly lower values of WSC compared to silages without inoculants and silages with freeze-dried inoculant associated with urea. This may be justified by the greater presence of active microorganisms in these silages during this fermentation period. It should be noted that, in the present study, the high WSC content is directly related to the rapid decrease in the $\mathrm{pH}$ [37].

The silages treated with urea showed high values of WSC for all fermentation periods (Table 4). At 70 days, the corn silage without additives showed the lowest WSC content $(67.09 \mathrm{~g} / \mathrm{kg} \mathrm{DM})$ when compared to those with additives ( $>80 \mathrm{~g} / \mathrm{kg} \mathrm{DM})$.

Corn plants had initial populations (before ensiling) of LAB of $5.50 \log \mathrm{cfu} / \mathrm{g}$ forage (Table 1). After $24 \mathrm{~h}$ of fermentation, all silages had populations of LAB above $8.0 \log \mathrm{cfu} / \mathrm{g}$ at forage (Table 4), with significantly higher values of $11.0 \mathrm{log} \mathrm{cfu} / \mathrm{g}$ at forage in the silages with preactivated inoculant $(p<0.05)$. The inoculation with active microorganisms promoted a greater development of LAB during the first $24 \mathrm{~h}$ of the fermentation process.

At 70 days after ensiling, populations of LAB stabilized at average values between 8.91 and $9.15 \mathrm{log} \mathrm{cfu} / \mathrm{g}$ in the silages with additives. In contrast, the silages without additives showed significantly lower values of $7.52 \mathrm{log} \mathrm{cfu} / \mathrm{g}$ forage $(p<0.05)$ (Table 4$)$. In studies of the microbiology in silages, [11] evaluated the effect of the inoculation of corn silages with LB and found values of $9.27 \mathrm{log} \mathrm{cfu} / \mathrm{g}$ forage for populations of $\mathrm{LAB}$ and $4.03 \log \mathrm{cfu} / \mathrm{g}$ forage of $\mathrm{Y}$ and $\mathrm{M}$, which are close to the present study.

Silages with urea showed the lowest values for $\mathrm{Y}$ and $\mathrm{M}$ (Table 4). After $24 \mathrm{~h}$ of the fermentation process, yeast populations were observed in silages treated with activated inoculant and urea (3.28 log cfu/g forage) and in silages with urea (3.12 log cfu/g forage) when compared to the initial populations of the plant. At 70 days of fermentation, the silages treated with urea differed significantly from the other silages $(p<0.05)$, with the lowest values of $Y$ and M (3.95 log cfu/g forage) (Table 4). Significantly higher values ( $5.17 \mathrm{log} \mathrm{cfu} / \mathrm{g}$ forage) were observed in silages inoculated with previously activated LB. The yeast inhibition as a function of urea treatment may be due to the buffering of the ensiled mass. Accordingly, [38] evaluated the effect of urea doses on sorghum silage and found that $Y$ and $\mathrm{M}$ reduced significantly in the ensiled mass from $1 \%$ urea in the dry matter, and ethanol production reduced almost totally when $2 \%$ urea was added. 
According to [5], the conversion from urea to ammonia in the ensiled mass acts on the $\mathrm{pH}$ of silages, raising it to an optimal range for the development of $\mathrm{LAB}$, thus preventing the growth of undesirable microorganisms in the silages. Urea also has fungistatic action on yeast metabolism. Yeasts depend strictly on the availability of a specific combination of carbon sources and nitrogen sources to be developed [21]. In corn plants, carbon sources for yeast growth, such as glucose, are generally not limiting factors. However, urea is a poor source of nitrogen for yeasts [18]. Therefore, the application of urea to silage promotes the addition of nitrogen in the silage, increasing the $\mathrm{NH}_{3}-\mathrm{N}$ concentration in the ensiled mass and delaying the development of yeasts since it imbalances the specific relationship of substrates for yeast growth [19].

\subsection{Chemical Composition}

No significant effect $(p<0.05)$ of treatments on the DM content of corn silages was observed in all opening periods (Table 5). The average values observed were within the range resulting from an adequate fermentation process with low effluent production (Table 2), which benefits the nutrient availability to the animal [39].

Table 5. Chemical composition of corn silages.

\begin{tabular}{|c|c|c|c|c|c|}
\hline \multirow{2}{*}{ Items $^{\dagger}$} & \multicolumn{5}{|c|}{ Fermentation Periods (Days) } \\
\hline & 1 & 3 & 7 & 14 & 70 \\
\hline \multicolumn{6}{|c|}{ Dry Matter (g/kg) } \\
\hline CS & 269.11 & 276.30 & 284.66 & 282.25 & 270.80 \\
\hline CSFDI & 278.09 & 277.58 & 283.63 & 275.29 & 271.01 \\
\hline CSFDIU & 283.39 & 277.00 & 283.44 & 283.89 & 285.81 \\
\hline CSAI & 279.93 & 279.12 & 282.99 & 278.20 & 285.39 \\
\hline CSAIU & 286.19 & 277.77 & 309.91 & 282.07 & 284.52 \\
\hline CSU & 281.99 & 249.75 & 282.97 & 282.93 & 282.43 \\
\hline$p$ value & 1.0000 & 0.9984 & 0.9998 & 0.6800 & 1.0000 \\
\hline \multicolumn{6}{|c|}{ Ash (g/kg DM) } \\
\hline CS & 35.19 & 39.53 & 36.97 & 3.82 & 33.37 \\
\hline CSFDI & 39.01 & 44.05 & 45.57 & 42.09 & 36.81 \\
\hline CSFDIU & 36.53 & 42.56 & 40.77 & 39.57 & 40.71 \\
\hline CSAI & 37.96 & 39.17 & 40.53 & 38.37 & 43.24 \\
\hline CSAIU & 37.02 & 35.96 & 40.49 & 38.56 & 38.88 \\
\hline CSU & 35.24 & 35.25 & 34.70 & 41.16 & 37.86 \\
\hline$p$ value & 0.9996 & 0.9812 & 0.9880 & 0.9977 & 0.9836 \\
\hline \multicolumn{6}{|c|}{ Crude Protein (g/kg DM) } \\
\hline CS & $69.65^{b}$ & $68.30^{b}$ & $57.18^{b}$ & $64.48^{b}$ & $82.15^{b}$ \\
\hline CSFDI & $63.53^{\mathrm{b}}$ & $67.70^{\mathrm{b}}$ & $71.84^{\mathrm{b}}$ & $71.08^{b}$ & $88.02^{b}$ \\
\hline CSFDIU & $106.10^{a}$ & $105.96^{\mathrm{a}}$ & $89.84^{\mathrm{a}}$ & $106.80^{\mathrm{a}}$ & $111.26^{\mathrm{a}}$ \\
\hline CSAI & $57.59^{b}$ & $73.52^{b}$ & $59.85^{b}$ & $73.29^{b}$ & $70.22^{c}$ \\
\hline CSAIU & $108.98^{a}$ & $99.65^{\mathrm{a}}$ & $99.05^{\mathrm{a}}$ & $106.55^{\mathrm{a}}$ & $111.10^{\mathrm{a}}$ \\
\hline CSU & $111.51^{\mathrm{a}}$ & $98.20^{\mathrm{a}}$ & $103.46^{\mathrm{a}}$ & $114.25^{\mathrm{a}}$ & $111.50^{\mathrm{a}}$ \\
\hline$p$ value & $<0.001$ & $<0.001$ & $<0.001$ & $<0.001$ & $<0.001$ \\
\hline \multicolumn{6}{|c|}{ Neutral Detergent Fiber (g/kg DM) } \\
\hline CS & 511.49 & 530.49 & 517.90 & 528.74 & 494.82 \\
\hline CSFDI & 496.15 & 539.47 & 508.93 & 505.23 & 498.15 \\
\hline CSFDIU & 474.40 & 474.58 & 499.46 & 490.33 & 502.74 \\
\hline CSAI & 498.28 & 520.04 & 488.18 & 496.04 & 505.55 \\
\hline CSAIU & 471.76 & 492.17 & 512.30 & 501.89 & 470.89 \\
\hline CSU & 475.32 & 487.73 & 498.47 & 501.96 & 475.12 \\
\hline$p$ value & 0.4225 & 0.0644 & 0.8187 & 0.6595 & 0.5513 \\
\hline
\end{tabular}

${ }^{\dagger}$ Items: CS, corn silage; CSFDI, corn silage with freeze-dried inoculant; CSFDIU, corn silage with freeze-dried inoculant $+1.0 \%$ urea; CSAI, corn silage with activated inoculant; CSAIU, corn silage with activated inoculant $+1.0 \%$ urea; CSU, corn silage with 1.0\% urea; means with different superscript letters in the columns are differed $(p<0.05)$. 
The ash of the studied corn silages did not show significant variations in all fermentation periods $(p>0.05)$ (Table 5). The treatment of the ensiled mass of corn with urea (isolated or associated with the inoculant) significantly increased $(p<0.05)$ the $\mathrm{CP}$ content of the silages. At 70 days of fermentation, the silages inoculated with activated bacteria had significantly lower values of CP (70.22 g/ $/ \mathrm{kg} \mathrm{DM})$.

Although corn silage is an excellent forage for ruminants due to its high digestible energy content, the addition of urea in forage silage contributes to increasing the nitrogen compounds of silages, suggesting the incorporation of most of the nitrogen added. Taking into consideration the rumen fermentation on the production of ruminants, the increased nitrogen fractions may be beneficial and promote the increased synthesis of microbial protein in the rumen $[40,41]$.

For the NDF content of silages, although several studies indicate the effect of the addition of urea on the fibrous fraction of forages, there was no significant effect $(p<0.05)$ of treatments on the NDF content in corn silages. It was expected that supplemented silages, mainly with urea and urea combined with the microorganism, would have lower values of NDF levels due to the control of the action of $\mathrm{Y}$ and $\mathrm{M}$. A possible explanation for the non-effect of these treatments may be related to the low dose of urea used, especially because much of the released ammonia is associated with the acids from the fermentation, forming salts, thereby not acting to cause alkaline hydrolysis of the fiber.

\subsection{Aerobic Stability}

After $96 \mathrm{~h}$ of exposure to the air, corn silages with freeze-dried inoculant and active urea inoculant had significantly higher final $\mathrm{pH}$ values (Table 6). However, they were not so high as to indicate a marked intake of lactic acid, suggesting that the ensiled mass was not spoiled. According to [36], the presence of oxygen during the storage or opening period of the silo favors the growth of aerobic microorganisms. The development of these microorganisms in the silage reduces the quality of the final food, implying high values of nutrient losses.

Table 6. Average values of maximum $\mathrm{pH}$, maximum values of yeasts and molds ( $\mathrm{Y}$ and $\mathrm{M}$ ), maximum temperature and aerobic stability in corn silages.

\begin{tabular}{|c|c|c|c|c|c|c|c|c|c|}
\hline & \multicolumn{6}{|c|}{ Treatments $^{\dagger}$} & \multirow{2}{*}{ Average } & \multirow{2}{*}{ CV (\%) } & \multirow{2}{*}{$p$ Value } \\
\hline & CS & CSFDI & CSFDIU & CSAI & CSAIU & CSU & & & \\
\hline Last $\mathrm{pH}^{*}$ & $4.16^{\mathrm{b}}$ & $4.49^{\mathrm{a}}$ & $4.24^{\mathrm{b}}$ & $4.22^{b}$ & $4.65^{\mathrm{a}}$ & $3.99^{b}$ & 4.22 & 6.40 & 0.048 \\
\hline $\mathrm{Y}$ and $\mathrm{M}$ & $9.69^{a}$ & $8.78^{a b}$ & $7.92^{b}$ & $8.57^{\mathrm{ab}}$ & $7.41^{\mathrm{b}}$ & $8.10^{\mathrm{b}}$ & 8.27 & 10.22 & 0.002 \\
\hline $\operatorname{VAMT}\left({ }^{\circ} \mathrm{C}\right)$ & $26.5^{a}$ & $26.0^{\mathrm{ab}}$ & $25.0^{\mathrm{b}}$ & $25.0^{\mathrm{b}}$ & $25.5^{b}$ & $25.0^{\mathrm{b}}$ & $25.5 \mathrm{~b}$ & 0.68 & 0.019 \\
\hline AS (h) & $62^{b}$ & $>96^{\mathrm{a}}$ & $>96^{\mathrm{a}}$ & $>96^{\mathrm{a}}$ & $>96^{\mathrm{a}}$ & $>96^{\mathrm{a}}$ & 96 & 13.36 & 0.030 \\
\hline
\end{tabular}

${ }^{\dagger}$ treatments: CS, corn silage; CSFDI, corn silage with freeze-dried inoculant; CSFDIU, corn silage with freeze-dried inoculant $+1.0 \%$ urea; CSAI, corn silage with activated inoculant; CSAIU, corn silage with activated inoculant $+1.0 \%$ urea; CSU, corn silage with $1.0 \%$ urea; * 96 h; VAMT, values average of maximum temperature; AS, aerobic stability; $\mathrm{CV}$, coefficient of variation. Means with different superscript letters in the rows are differed $p<0.05$ ).

The $\mathrm{Y}$ and $\mathrm{M}$ recorded in corn silages without inoculants were significantly higher than those treated with urea $(p<0.05)$ (Table 6). Urea acts on the silage by increasing the $\mathrm{pH}$ values of the medium, reducing the potential for the development of yeast populations. On the other hand, the positive effect of urea during oxygen exposure may be associated with the lower $\mathrm{Y}$ and $\mathrm{M}$ at the time of opening, which may have been inhibited by the urea buffering and antifungal activity during the silage fermentation phase [21].

The maximum temperature values were highest in the corn silages without additives $(p<0.05)$ (Table 6), indicating that these silages were more prone to deterioration.

The average temperature values of the silages inoculated and supplemented with urea were kept below $2{ }^{\circ} \mathrm{C}$ at room temperature, and no loss of aerobic stability was detected for these silages up to the $96 \mathrm{~h}$ aerobic period. However, corn silages without additives had a stability loss at $62 \mathrm{~h}$ from exposure to air. It is known that the aerobic deterioration is due to the initial action of yeasts using LA, and that it is common in untreated corn silages to break aerobic stability due to the performance of 
these yeasts, which makes the environment prone to the development of molds and aerobic bacteria, causing silage deterioration.

The increase in aerobic stability in the supplemented silages was due to the inhibition of yeast growth. Yeasts are indicated as the first microorganisms involved in the deterioration of silages, promoting an environment suitable for the development of other aerobic microorganisms involved in the aerobic deterioration of the ensiled mass [34]. In a microbiology study, [12] observed $53 \mathrm{~h}$ of aerobic stability in a corn silage without additives, while corn silages inoculated with LB reached $112 \mathrm{~h}$ of stability after exposure to air.

It is noteworthy that the increased availability of acetic acid from inoculation with LB strains reduced the development of microorganisms deleterious to the silage. The associative effect of the inoculant with urea is therefore evident. Even the non-activated inoculant ensured the aerobic stability for up to $96 \mathrm{~h}$, higher than the observed in the treatment without an additive, which is reported in the literature as a beneficial effect of the inoculation with LB. Paradoxically, the previous activation allowed beneficial effects already in the fermentative phase and can be considered given the simplicity of the activation process.

In summary, the inoculation once again proved efficient in increasing the aerobic stability of silages. However, the positive effects on the fermentation and the nutritional value of silages can be a decisive factor in the use of both additives in corn silage. It should also be taken into account that the control of $\mathrm{Y}$ and $\mathrm{M}$ during oxygen exposure is a factor positively related to the intake of silages. Furthermore, urea is commonly used as a protein source in ruminant diets. Its use as an additive in silage, due to the improvements observed in the fermentation, aerobic stability and nutritional value while maintaining a high protein value of the silage, can facilitate the formulation of rations.

\section{Conclusions}

The use of Lactobacillus Buchneri activated proved to be more efficient in improving the fermentative profile of corn silage than freeze-dried inoculant. The use of urea as an additive reduced the losses and improved the nutritional value and aerobic stability of corn silages. Additionally, the combination of Lactobacillus buchneri activated and urea may be used as a technique to improve the fermentative profile, chemical composition and aerobic stability of corn silages.

Author Contributions: Conceptualization, A.P.M.d.S., E.M.S., G.G.L.d.A., J.S.d.O., A.d.M.Z., R.M.A.P., G.F.d.L.C., D.d.J.F., A.F.P., D.M.P., and F.N.d.S.S.; methodology, A.P.M.d.S., E.M.S., G.G.L.d.A., J.S.d.O., A.d.M.Z., R.M.A.P., G.F.d.L.C., D.d.J.F., A.F.P., D.M.P., and F.N.d.S.S.; software, E.M.S., G.G.L.d.A., R.M.A.P., A.P.M.d.S., A.d.M.Z., and J.S.d.O.; validation, E.M.S., A.P.M.d.S., and. J.S.d.O.; formal analysis, A.P.M.d.S., E.M.S., R.M.A.P., G.G.L.d.A., and L.S.; investigation, A.F.P., D.M.P.; D.D.J.F., and F.N.d.S.S.; resources E.M.S., G.G.L.d.A., A.P.M.d.S., and R.M.A.P.; data curation, E.M.S., A.d.M.Z., J.S.d.O., and A.F.P.; writing-original draft preparation, A.P.M.d.S., E.M.S., R.M.A.P., A.d.M.Z., and J.S.d.O.; writing-review and editing, A.P.M.d.S., E.M.S., D.M.P.; F.N.d.S.S.; and J.S.d.O.; visualization A.P.M.d.S., E.M.S., G.G.L.d.A., J.S.d.O., A.d.M.Z., R.M.A.P., G.F.d.L.C., and D.M.P.; supervision, E.M.S., R.M.A.P., A.d.M.Z., G.G.L.d.A., and J.S.d.O.; project administration, E.M.S., J.S.d.O., G.G.L.d.A., and A.d.M.Z.; funding acquisition, E.M.S. and J.S.d.O. All authors have read and agreed to the published version of the manuscript.

Funding: This research received funding from the Coordination for the Improvement of Higher Education Personnel (CAPES-Brazil) and Maranhão State Research Foundation (FAPEMA).

Acknowledgments: The authors wish to thank the Coordination for the Improvement of Higher Education Personnel (CAPES) and the authors also wish to thank the FAPEMA (Maranhão State Research Foundation) for its financial support.

Conflicts of Interest: The authors declare no conflict of interest.

\section{References}

1. Teller, R.S.; Schmidt, R.J.; Whitlow, L.W.; Kung, L., Jr. Effect of physical damage to ears of corn before harvest and treatment with various additives on the concentration of mycotoxins, silage fermentation and aerobic stability of corn silage. J. Dairy Sci. 2012, 95, 1428-1436. [CrossRef] [PubMed] 
2. Ferreira, D.J.; Zanine, A.M.; Lana, R.P.; Souza, A.L.; Negrão, F.M.; Parente, H.N.; Parente, M.O.M.; Geron, L.J.V.; Pinho, R.M.A. Fermentation and chemical composition of Marandu grass ensiled with dehydrated brewery residue. Grassl. Sci. 2019, 65, 69-72. [CrossRef]

3. Silva, J.; Winckler, J.P.P.; Kristensen, N.B.; Daniel, J.L.P.; Nussio, L.G. Effects of Lactobacillus buchneri inoculation or 1-propanol supplementation to corn silage on the performance of lactating Holstein cows. Braz. J. Anim. Sci. 2017, 46, 591-598. [CrossRef]

4. Sariçiçek, Z.; Kiliç, U. The effects of different additives on silage gas production, fermentation kinetics and silage quality. Ozean J. Appl. Sci. 2009, 2, 140-151.

5. Muck, R.E. Silage microbiology and its control through additives. Braz. J. Anim. Sci. 2010, 39, 83-191. [CrossRef]

6. Weinberg, Z.G.; Khanal, P.; Yildiz, C.; Chen, Y.; Arieli, A. Ensiling fermentation products and aerobic stability of corn and sorghum silages. Grassl. Sci. 2001, 57, 46-50. [CrossRef]

7. Bedrosian, M.C.D.; Kung, L., Jr. The effect of various doses of an exogenous acid protease on the fermentation and nutritive value of corn silage. J. Dairy Sci. 2019, 102, 10925-10933. [CrossRef]

8. Pahlow, G.R.E.; Muck, F.; Oude Elferink, S.J.W.H.; Spoesltra, S.F. Microbiology of ensiling. In Silage Science and Technology; American Society of Agronomy: Madison, WI, USA, 2003; Volume 22, pp. 31-94. [CrossRef]

9. Silva, T.C.; Smith, M.L.; Barnard, A.M.; Kung, L., Jr. The effect of a chemical additive on the fermentation and aerobic stability of high-moisture corn. J. Dairy Sci. 2015, 98, 1-12. [CrossRef]

10. Muck, R.E.; Nadeau, E.M.G.; McAllister, T.A.; Govea, F.E.C.; Santos, M.C.; Kung, L., Jr. Silage review: Recent advances and future uses of silage additives. J. Dairy Sci. 2018, 101, 3980-4000. [CrossRef]

11. Kleinschmit, D.H.; Kung, L., Jr. A meta-analysis of the effects of Lactobacillus buchneri on the fermentation and aerobic stability of corn and grass and small-grain silages. J. Dairy Sci. 2006, 89, 4005-4013. [CrossRef]

12. Hu, W.; Schmidt, R.J.; Mcdonell, E.E.; Klingerman, C.M.; Kung, L., Jr. The effect of Lactobacillus buchneri 40788 or Lactobacillus plantarum MTD-1 on the fermentation and aerobic stability of corn silages ensiled at two dry matter contents. J. Dairy Sci. 2009, 92, 3907-3914. [CrossRef] [PubMed]

13. Schmidt, R.J.; Kung, L., Jr. The effects of Lactobacillus buchneri with or without a homolactic bacterium on the fermentation and aerobic stability of corn silages made at different locations. J. Dairy Sci. 2010, 93, 1616-1624. [CrossRef] [PubMed]

14. Zhang, F.; Wang, X.; Lu, W.; Li, F.; Ma, C. Improved quality of corn silage when combining cellulose-decomposing bacteria and Lactobacillus buchneri during silage fermentation. BioMed Res. Int. 2019. [CrossRef] [PubMed]

15. Oude Elferink, S.J.W.H.; Krooneman, J.; Gottschal, J.C.; Spoelstra, S.F.; Faber, F.; Driehuis, F. Anaerobic conversion of lactic acid to acetic acid and 1,2-propanediol by Lactobacillus buchneri. Appl. Environ. Microbiol. 2001, 67, 125-132. [CrossRef]

16. Nsereko, V.L.; Smiley, B.K.; Rutheford, W.M.; Spielbauer, A.; Forrester, K.J.; Hettinger, G.H.; Karman, E.K.; Harman, B.R. Influence of inoculation forage with lactic acid bacteria strains that produce ferulate esterase on ensilage and ruminal degradation of fiber. Anim. Feed Sci. Technol. 2008, 145, 122-135. [CrossRef]

17. Fernandes, F.E.P.; Garcia, R.; Pires, A.J.V.; Pereira, O.G.; Carvalho, G.G.P.; Olivindo, C.S. Ensilage of forage sorghum with addition of urea in two storage periods. Braz. J. Anim. Sci. 2009, 38, 2111-2115. [CrossRef]

18. Araki, H.C.M.; Oliveira, E.R.; Gandra, J.R.; Goes, R.H.T.B.; Takiya, C.S.; Jacaúna, A.G.; Oliveira, K.M.P.; Vasques, D.N.; Cônsolo, N.R.; Valle, T.A.; et al. Association of biological and chemical additives on nutrient composition, total losses, microbiological and fermentative profile of sugarcane silage. Iran. J. Appl. Anim. Sci. 2017, 7, 577-584.

19. Vieira, D.A.; Cezário, A.S.; Valente, T.N.P.; Ribeiro, J.C.; Santos, W.B.R.; Ferreira, P.R.N. Evaluation of the addition of urea or calcium oxide $(\mathrm{CaO})$ on the recovery of dry matter of the by-product of sweet corn silage. J. Agric. Sci. 2017, 9, 141-148. [CrossRef]

20. Hess, D.C.; Lu, W.; Rabinowitz, J.D.; Botstein, D. Ammonium toxicity and potassium limitation in yeast. PLoS Biol. 2006, 4, e351. [CrossRef]

21. Vandersluis, B.; Hess, D.C.; Pesyna, C.; Krumhol, E.W.; Syed, T.; Szappanos, R.; Nislow, C.; Papp, B.; Troyanskaya, O.G.; Myers, C.L.; et al. Broad metabolic sensitivity profiling of a prototrophic yeast deletion colletion. Genome Biol. 2014, 15, 1-18. [CrossRef]

22. Neumann, M.; Oliboni, R.; Oliveira, R.M.; Faria, M.V.; Ueno, R.K.; Reinerh, L.L.; Durman, T. Aditivos químicos utilizados em silagens. Appl. Res. Agrot. 2010, 3, 115-121.

23. Santos, E.M.; Zanine, A.M.; Ferreira, D.J.; Oliveira, J.S.; Penteado, D.C.S.; Pereira, O.G. Activated inoculant improves Tanzania grass (Panicum maximum) silage. Arch. Zootec. 2008, 57, 35-42. 
24. De Man, J.C.; Rogosa, M.; Sharpe, M.E. A medium for the cultivation of lactobacilli. J. Appl. Bacteriol. 1960, 23, 130-135. [CrossRef]

25. Zanine, A.M.; Santos, E.M.; Dórea, J.R.R.; Dantas, P.A.D.S.; Silva, T.C.; Pereira, O.G. Evaluation of elephant grass with addition of cassava scrapings. Braz. J. Anim. Sci. 2010, 39, 2611-2616. [CrossRef]

26. Association of Official Analytical Chemists (AOAC). Association of Official Analytical Chemists; Official Methods of Analysis of AOAC: Urbana, IL, USA, 2005.

27. Mertens, D.R. Gravimetric determination of amylase treated neutral detergent fiber in feeds with refluxing in beaker or crucibles: Collaborative study. J. Aoac Int. 2002, 85, 1217-1240. [CrossRef]

28. Siegfried, R.; Ruckemann, H.; Stumpf, G. Method for the determination of organic acids in silage by high performance liquid chromatography. Landwirtsch. Forsch. 1984, 37, 298-304. [CrossRef]

29. Bolsen, K.K.; Li, C.; Brent, C.R.; Feverherm, A.M.; Urban, J.E.; Aimutis, W.R. Effects of silage additives on the microbial succession and fermentation process of alfafa and corn silages. J. Dairy Sci. 1992, 75, 3066-3083. [CrossRef]

30. Dubois, M.; Gilles, K.A.; Hamilton, J.K.; Rebers, P.A.; Smith, F. Colorimetric method for determination of sugars and related substances. Anal. Biochem. 1956, 28, 350-356. [CrossRef]

31. Taylor, C.C.; Kung, L., Jr. The effect of Lactobacillus buchnneri 40788 on the fermentation and aerobic stability of high moisture corn in laboratory silos. J. Dairy Sci. 2002, 85, 1526-1532. [CrossRef]

32. Zanine, A.M.; Bonelli, E.A.; Souza, A.L.; Ferreira, D.J.; Santos, E.M.; Pinho, R.M.A.; Parente, H.N.; Parente, M.O.M. Fermentation and chemical composition of guinea grass silage added with wheat meal and Streptococcus bovis. N. Z. J. Agric. Res. 2018, 45, 1-8. [CrossRef]

33. Santos, E.M.; Silva, T.C.; Macedo, C.H.O.; Campos, F.S. Lactic acid bacteria in tropical grass silages. In Lactic Acid Bacteria-R \& D for Food, Health and Liv Purpose; Intech: London, UK, 2013; pp. 335-362. [CrossRef]

34. Woolford, M.K. A review: The detrimental effects of air on silage. J. Appl. Bacteriol. 1990, 68, 101-116. [CrossRef] [PubMed]

35. McDonald, P.; Henderson, A.R.; Heron, S. The Biochemistry of Silage; Marlow: Chalcombe, UK, 1991; p. 340.

36. Pozza, M.S.S.; Pozza, P.C.; Tsutsumi, C.Y.; Almeida, R.Z.; Nunes, R.V.; Sabedot, M.A.; Zambom, M.A. Microbial populations and chemical composition of corn silage. Sci. Agric. Par. 2011, 10, 91-99.

37. Zanine, A.M.; Bonelli, E.A.; Souza, A.L.; Ferreira, D.J.; Santos, E.M.; Ribeiro, M.D.; Geron, L.J.V.; Pinho, R.M.A. Effects of Streptococcus bovis isolated from bovine rumen on the fermentation characteristics and nutritive value of tanzania grass silage. Sci. World J. 2016, 23, 1-6. [CrossRef]

38. Santos, A.P.M.; Santos, E.M.; Oliveira, J.S.; Ribeiro, O.L.; Perazzo, A.F.; Pinho, R.M.A.; Macêdo, A.J.S.; Pereira, G.A. Effects of urea addition on the fermentation of sorghum (Sorghum bicolor) silage. Afr. J. Range Forage Sci. 2018, 35, 55-62. [CrossRef]

39. Van Soest, P.J. Nutritional Ecology of the Ruminant; Cornell: Ithaca, UK, 1994; p. 476.

40. Boucher, S.E.; Ordway, R.S.; Whitehouse, N.L.; Lundy, F.P.; Kononoff, P.J.; Schwab, C.G. Effect of incremental urea supplementation of a conventional corn silage-based diet on ruminal ammonia concentration and synthesis of microbial protein. J. Dairy Sci. 2007, 90, 5619-5633. [CrossRef]

41. Oliveira, A.C.; Pires, A.J.V.; Oliveira, H.C.; Patês, N.M.S.; Fonsêca, M.P.; Carvalho, G.G.P.; Neto, U.M.; Oliveira, U.L.C.; Aguiar, L.V.; Oliveira, A.B. Nitrogen composition of tropical grass silages treated with urea. Arch. Zootec. 2007, 56, 15-21.

(C) 2020 by the authors. Licensee MDPI, Basel, Switzerland. This article is an open access article distributed under the terms and conditions of the Creative Commons Attribution (CC BY) license (http://creativecommons.org/licenses/by/4.0/). 